\title{
The toxicity of coated silver nanoparticles to the alga Raphidocelis subcapitata
}

\author{
Sam Lekamge ${ }^{1,3}$ (1) $\cdot$ Ana F. Miranda ${ }^{1} \cdot$ Amanda Abraham $^{2} \cdot$ Andrew S. Ball $^{3} \cdot$ Ravi Shukla $^{2} \cdot$ Dayanthi Nugegoda $^{1,3}$
}

Received: 7 August 2019 / Accepted: 5 March 2020 / Published online: 10 March 2020

(c) Springer Nature Switzerland AG 2020

\begin{abstract}
The use of silver nanoparticles (AgNPs) is growing exponentially, especially in consumer products due to their excellent antimicrobial properties. However, concerns are growing on their possible negative effects on environmental and human health. AgNPs from consumer products enter aquatic ecosystems where their physicochemical properties including surface functionalization are critical to their impact on aquatic organisms. The effects of AgNPs coated with three different ligands; tyrosine (T-AgNP), epigallocatechin gallate (E-AgNP) and curcumin (C-AgNP) and $\mathrm{Ag}^{+}$ions on the freshwater green alga Raphidocelis subcapitata were investigated. Stability tests of AgNPs revealed that the coating significantly affects the fate and behaviour of AgNPs. All types of AgNPs tested and ionic silver were found to be toxic to the alga and differential growth inhibition of algae were observed from differently coated AgNPs, with the $48 \mathrm{~h} \mathrm{EC}{ }_{50}$ of C-AgNPs, T-AgNPs and E-AgNPs being $0.155,0.163$ and $0.243 \mathrm{mg} \mathrm{L}^{-1}$, respectively, in comparison with $0.051 \mathrm{mg} \mathrm{L}^{-1}$ for $\mathrm{Ag}^{+}$ions. Associated $\mathrm{Ag}$ in the algae increased with increased concentrations of all $\mathrm{AgNPs}$ and $\mathrm{Ag}^{+}$ions and the toxicity positively correlated to the associated Ag content in algae. The antioxidant enzymes glutathione S-transferase and catalase were activated in algal cells by the AgNPs and $\mathrm{Ag}^{+}$ions, but a consistent difference in response was not identified with different concentrations of NPs. This study shows the effects of the surrounding environment and surface functionalization of AgNPs on algae highlighting the importance of considering them in environmental risk assessment of AgNPs.
\end{abstract}

Keywords Silver $\cdot$ Nanoparticles $\cdot$ Coating $\cdot$ Algae $\cdot$ Toxicity $\cdot$ Bioaccumulation

\section{Introduction}

Nano-silver is already highly commercialized, and its applications are growing, mainly due to its excellent antimicrobial qualities. It is one of the most widely used nanoparticles (NPs) [105] occurring in $25 \%$ of all nano-based products [13]. The nanodatabase [59] currently lists 540 commercial products that contain silver nanoparticles (AgNPs) which are available to the European market.
Healthcare, electronics, textile and food and beverage industries are the largest segments of AgNPs [14, 31, 53]. Their global consumption is estimated to rise to 450 metric tonnes per year [47], and the global market for Ag NPs is expected to reach USD 2.45 billion by 2022 [32]. Silver NPs in most consumer products will end up in the environment including natural aquatic systems [96]. Despite many advantages, extensive usage of Ag NPs may cause environmental pollution and concerns are rising about

Electronic supplementary material The online version of this article (https://doi.org/10.1007/s42452-020-2430-z) contains supplementary material, which is available to authorized users.

$\triangle$ Sam Lekamge, samlekamge@gmail.com | ${ }^{1}$ Ecotoxicology Research Group, School of Science, RMIT University, Bundoora West Campus, Bundoora, VIC 3083, Australia. ${ }^{2}$ Nanobiotechnology Research Laboratory, RMIT University, GPO Box 2476, Melbourne, VIC 3001, Australia. ${ }^{3}$ Centre for Environmental Sustainability and Remediation, School of Science, RMIT University, Bundoora West Campus, Bundoora, VIC 3083, Australia. 
their possible impacts on ecosystem and human health. New uses of AgNPs are continuously being discovered, yet the environmental implications are not fully understood [48, 92].

Algae play an important role in the aquatic ecosystem as the primary producers in the food web [46]. Primary producers in the aquatic system are vulnerable and are targeted first by contaminants. Any adverse effects to the autotrophs will have an effect on the heterotrophs $[18,49]$. Several studies have proven that AgNPs are toxic to algae $[25,44]$. Also, algae serve as a model organism to assess effects of NPs in aquatic systems [80]. Studies on NP toxicity so far concluded that either or both NPs and liberated ions from NPs could cause toxicity $[79,81]$.

Physicochemical characteristics of both NPs and the surrounding environment influence the toxicity of NPs $[5,45]$. Size, shape, surface chemistry, chemical composition, surface area and crystal structure are all intrinsic NP properties $[9,16,72,83]$; ionic strength, $\mathrm{pH}$, the presence of natural organic matter and hardness are media-specific properties that affect toxicity of NPs $[48,91]$. Biofunctionalized AgNPs are used in many applications [33, 73]. The effects of this surface functionalization of NPs on their physicochemical characteristics, fate and toxicity to organisms are critical, but not well understood yet $[1,78]$ which warrants further research.

Uptake of NPs is a crucial factor in assessing the effects of NPs [12]. When Ag NPs are associated with algae, it is possible for them to transfer up the food web [49]. Several researchers have reported uptake of AgNPs by algae [41, $50,67,69]$. Further, it is widely accepted that the AgNPs cause oxidative damage $[65,71,93]$. Silver NPs cause the generation of reactive oxygen species (ROS) which lead to activation of the antioxidant system resulting in increased production of antioxidants $[39,54]$. The antioxidant status of an organism can be used to assess oxidative stress and therefore represents a good indicator to evaluate the effects of NPs [98].

This study was aimed at understanding the effects of AgNPs coated with three different organic ligands: tyrosine-coated (T-AgNP), curcumin-coated (C-AgNP) and epigallocatechin gallate-coated (E-AgNP) and $\mathrm{Ag}^{+}$ions on the freshwater green alga Raphidocelis subcapitata. Tyrosine, Curcurmin and Epigallocatechin gallate have different number of phenol structures and classified as monophenol, biphenol and polyphenols, respectively. These ligands act as reducing and stabilizing agents in NP synthesis [36] and are widely studied for different applications $[17,42,82]$ including therapeutic applications where their organic nature makes them biocompatible $[20,27]$. Despite increasing usage, comparative studies on effects of NPs coated with different organic coatings on aquatic organisms are relatively scarce. The production and characterization of the NPs used were performed in-house and the stability of NPs in the algae medium, their toxicity, bioaccumulation and effects on antioxidant enzyme activity were all assessed upon acute (72 h) exposure of algae to AgNPs and $\mathrm{Ag}^{+}$ionic suspensions.

\section{Materials and methods}

\subsection{Preparation of NPs}

L-tyrosine, epigallocatechin gallate (EGCG) and curcumin (Fig. S.1A-C) were purchased from Sigma-Aldrich and the NP synthesis was done in-house by following the method described at Selvakannan et al. [82]. Equal volumes $\left(10 \mathrm{~mL}\right.$ ) of $10^{-3} \mathrm{M} \mathrm{Ag}_{2} \mathrm{SO}_{4}$ and $10^{-3} \mathrm{M}$ of tyrosine, EGCG or curcumin solutions were mixed and diluted to $100 \mathrm{~mL}$ with MilliQ water. Then, $1 \mathrm{~mL}$ of $10^{-1} \mathrm{M} \mathrm{KOH}$ solution was added, and the mixture was boiled until the colour turned to yellow. After $24 \mathrm{~h}$, the AgNP solutions were concentrated by rotary evaporation. Any uncoordinated silver ions, excess $\mathrm{KOH}$ and unbound coating materials in the solutions were removed by dialysing for $48 \mathrm{~h}$ in a dialysis tube (MWCO: $3 \mathrm{kDa}$ ) submerged in MilliQ water which was replaced twice after 6 and $24 \mathrm{~h}$. The AgNP solutions $(0.1 \mathrm{~mL})$ were acid digested with ultra-pure grade $70 \% \mathrm{HNO}_{3}$ (Thermo Fisher Scientific, NSW, Australia) on a heating block $\left(105^{\circ} \mathrm{C}\right)$ for $12 \mathrm{~h}$ and diluted with MilliQ water before measuring silver $\left(\mathrm{Ag}^{+}\right)$concentration with inductively coupled plasma mass spectrometry (ICP-MS) (7700x, Agilent Technologies).

\subsection{Characterization of NPs}

The surface plasmon resonance (SPR) analysis of AgNPs was performed using a UV-visible spectrophotometer (Varian Cary 50) in a quartz cuvette with a path length of $1 \mathrm{~cm}$. The hydrodynamic diameter (HDD) and the zeta potential of NPs was measured in a Zetasizer (Dynamic light scattering; Malvern Zetasizer Nano series, NanoZS) using a folded capillary cell and a glass cuvette, respectively. To determine the core size of AgNPs, the NP solutions were drop casted on carbon-coated copper grids following which the extra solution was removed using a blotting paper, and the grid was allowed to dry prior to measurement. The images were obtained by a transmission electron microscopy (TEM) operated at $100 \mathrm{kV}$ (JEOL 1010) equipped with a Gatan imaging system. The mean core size of AgNPs were determined by analysing 50-150 NPs by ImageJ software. 


\subsection{AgNP temporal stability and dissolution in the test medium}

The stability of AgNPs in the algae medium and MilliQ water was investigated using the modified methods of Tejamaya et al. [94]. Nanoparticle solutions of $5 \mathrm{mg} \mathrm{L}^{-1}$ were incubated in glass vials for $72 \mathrm{~h}$ at similar environmental conditions used for algae toxicity test. The SPR, HDD and zeta potential of the suspensions were investigated, and $\mathrm{pH}$ was monitored at $0,24,48$ and $72 \mathrm{~h}$. The release of $\mathrm{Ag}^{+}$ions from NPs in the algae medium and MilliQ water was investigated at $0,24,48$ and $72 \mathrm{~h}$ as described previously by Xia et al. [101] with some modifications. Briefly, $1 \mathrm{~mL}$ from each NP suspension was extracted into Eppendorf tubes in triplicate and centrifuged at 21,000 rpm for $15 \mathrm{~min}$ (Sigma 3-KL centrifuge). Supernatant $(0.75 \mathrm{~mL})$ from carefully removed tubes was transferred to $15 \mathrm{~mL}$ tubes, diluted with MilliQ water and acidified (2\%) with $\mathrm{HNO}_{3}$. The $\mathrm{Ag}^{+}$ion concentrations were measured by ICP-MS (7700x, Agilent Technologies).

\subsection{Algae growth inhibition test}

Algae growth inhibition tests with alga $R$. subcapitata were conducted as per the OECD guidelines with some adaptations [63]. Algae cells from a pure culture were inoculated into MLA medium [11] and algal cells were counted periodically. The test was started when the algae growth rate was at the exponential stage. Algal biomass was adjusted to $5 \times 10^{4}$ cells $\mathrm{mL}^{-1}$ in each flask which contains $40 \mathrm{~mL}$ of test solution. Silver NP test solutions of $0.020,0.050,0.080$, $0.110,0.140,0.170,0.200$ and $0.230 \mathrm{mg} \mathrm{L}^{-1}$ were prepared by dispersing relevant volumes of NP stock solutions in algae culture. lonic silver stock solution was prepared by dissolving $\mathrm{Ag}_{2} \mathrm{SO}_{4}$ in MilliQ water and test solutions of $0.010,0.020,0.040,0.060,0.080,0.100$ and $0.120 \mathrm{mg} \mathrm{L}^{-1}$ $\mathrm{Ag}^{+}$ion concentrations were prepared by dissolving relevant volumes from the stock solution. All treatments were tested in triplicate while six controls with only M4 medium and algae were incubated using the same algal cell concentration.

Flasks were kept on shakers (100 rpm) (OM6, RATEK, Aus) to allow mixing and $\mathrm{CO}_{2}$ diffusion and incubated in a light-temperature controlled chamber under continuous illumination $(6000 \mathrm{~lx})$ at $23 \pm 1{ }^{\circ} \mathrm{C}$. White fluorescent tubes were used as the light source while the light intensity in the test setup was measured using a LI-COR light meter (model LI-189). Flasks were manually shaken every $24 \mathrm{~h}$ to resuspend any settled cells and $\mathrm{pH}$ was monitored throughout the testing period. Samples $\left(50 \mu \mathrm{g} \mathrm{L}^{-1}\right)$ were taken from each vessel at 24,48 and $72 \mathrm{~h}$ and the number of cells were quantified by measuring fluorescence intensity as described by Aruoja et al. [8]. Briefly, algae samples
$(50 \mu \mathrm{L})$ were added to $200 \mu \mathrm{L}$ of ethanol in triplicate in a 96 well plate and the plate was shaken for $3 \mathrm{~h}$ in the dark. Fluorescence intensity was measured with a fluorescence spectrophotometer (POLARstar omega, BMG Labtech) using an excitation wavelength of $400 \pm 80 \mathrm{~nm}$ and emission wavelength of $600 \pm 80 \mathrm{~nm}$. The nanoparticle suspensions neither fluoresced nor absorbed any light under these conditions. Chlorophyll fluorescence correlated with the cell density which was determined and calibrated by cell counting with a $\mathrm{TC}^{\mathrm{T}} \mathrm{T}^{\mathrm{Tm}}$ Automated Cell Counter, BioRad Laboratories, Hercules, CA. Microscopic observations were performed to verify the healthy appearance of the inoculum culture and to verify readings inferred with data obtained with fluorescence microscopy. All experiments were conducted under aseptic conditions. The specific growth rate was calculated as the logarithmic increase in the biomass of each single vessel using the following equations:

$\mu_{i-j}=\frac{\left(\ln X_{j}-\ln X_{i}\right)}{\left(t_{j}-t_{i}\right)}$

where $\mu_{i-j}$ is the average specific growth rate from time $i$ to time $j, X_{j}$ is the biomass at time $j$ and $X_{i}$ is the biomass at time $i$.

The percentage inhibition of growth rate for each treatment was calculated as:

$\% I_{\mathrm{r}}=\frac{\left(\mu_{\mathrm{c}}-\mu_{\mathrm{T}}\right)}{\mu_{\mathrm{c}}} \times 100$

where $\% I_{r}$ is the percentage inhibition in average specific growth rate, $\mu_{c}$ is the mean value for average specific growth rate in the control group and $\mu_{\mathrm{T}}$ is the average specific growth rate for the treatment replicate.

The biomass in the control cultures increased exponentially in the range of 17-22 within the 72-h test period and the coefficient of variation of average specific growth rates in replicate control cultures were less than $7 \%$, thus fulfilling the OECD validity criteria [64].

\subsection{Algae digestion and metal analysis}

Algae digestion and metal analysis were carried out as described by Li et al. [50] and Miller et al. [57]. Briefly, $30 \mathrm{~mL}$ of AgNP-exposed algae cultures from each flask were concentrated by centrifugation in $50 \mathrm{~mL}$ polypropylene tubes at $3500 \mathrm{~g}$ for $15 \mathrm{~min}$ (Heraeus Multifuge 1S-R, Thermoscientific) and resuspended in MilliQ water. After 2 wash cycles, algae were washed with $0.5 \mathrm{mM}$ cysteine-MOPS for $5 \mathrm{~min}$ to remove metals loosely bound to the surface as described and validated previously $[50,67]$. Algae were then filtered (SM16510, Sartorius) and acid digested with 
ultra-pure grade $70 \% \mathrm{HNO}_{3}$ and $30 \% \mathrm{H}_{2} \mathrm{O}_{2}$ at $105^{\circ} \mathrm{C}$ for $6 \mathrm{~h}$. The digested samples were diluted with MilliQ water and the silver $\left(\mathrm{Ag}^{+}\right)$concentrations were measured with ICP-MS. The number of algal cells in each sample $(30 \mathrm{~mL})$ chosen for metal analysis were extrapolated from the data obtained for algae growth inhibition calculations in the section above. The measured silver content after wash cycles was operationally defined as the cell-associated sil$\operatorname{ver}\left(\mathrm{Ag}_{\text {cell }}\right)$ and expressed as nanograms per cell $\left(\mathrm{ng} \mathrm{cell}^{-1}\right)$.

\subsection{GST and CAT enzyme activity assays}

Enzyme activity assays were conducted as described by Melegari et al. [54] with some modifications. Aliquots of $200 \mathrm{~mL}$ algae culture $\left(1 \times 10^{6}\right.$ cells $\left.\mathrm{mL}^{-1}\right)$ at the exponential growth phase were exposed to AgNPs and $\mathrm{Ag}^{+}$ions $\left(0.1,0.2,0.4\right.$ and $\left.0.8 \mathrm{mg} \mathrm{L}^{-1}\right)$ for $72 \mathrm{~h}$ at conditions similar to the above described toxicity test. Controls did not include contaminants and all samples were exposed in triplicate. After exposure, algal cultures were collected, centrifuged at $3500 \mathrm{~g}$ for $15 \mathrm{~min}$ (Heraeus Multifuge 1S-R, Thermoscientific) and the pellets were resuspended in $400 \mu \mathrm{L}$ of $0.1 \mathrm{M}$ phosphate buffer $(\mathrm{pH} 6.5)$ for glutathione S-transferase (GST) analysis and $800 \mu \mathrm{L}$ of $0.05 \mathrm{M}$ phosphate buffer ( $\mathrm{pH} 7)$ for catalase (CAT) analysis. The suspensions were homogenized in $2 \mathrm{~mL}$ lysing tubes (FastPrep ${ }^{\mathrm{TM}}$, $\mathrm{MP}$ bio) using a FastPrep-24 ${ }^{\mathrm{TM}} 5 \mathrm{G}$ Homogenizer, MP bio and centrifuged at $9000 \mathrm{~g}$ for $30 \mathrm{~min}$ at $4{ }^{\circ} \mathrm{C}$ (Sigma 3-16 KL centrifuge) for GST analysis and $15,000 \mathrm{~g}$ for $15 \mathrm{~min}$ at $4{ }^{\circ} \mathrm{C}$ for CAT analysis. The supernatants were stored at $-80^{\circ} \mathrm{C}$. GST activity was evaluated as described by Habig et al. [34] adapted to a microplate [29]. CAT activity was evaluated as described by Aebi [2]. The optical absorbance was measured at $340 \mathrm{~nm}$ for GST and at $240 \mathrm{~nm}$ for CAT by UV-visible spectrophotometer (POLARstar Omega, BMG Labtech). GST and CAT activity was expressed as micro moles $(\mu \mathrm{M})$ or milli moles $(\mathrm{mM})$ of substrate $\left(\mathrm{H}_{2} \mathrm{O}_{2}\right)$ hydrolysed per min per $\mathrm{mg}$ of protein, respectively.

\subsection{Calculation of $\mathrm{EC}_{50}$ values and statistical analysis}

All Effective concentration $\left(E C_{x}\right)$ calculations were conducted using the software ToxRat Professional v 3.0.0 (ToxRat Solutions, Aachen, Germany). Data from bioassays were analysed by a two-way ANOVA followed by Bonferroni $t$ test for multiple comparison of means. Shapiro-Wilk's test was performed to check the normal distribution followed by Levene's test for variance homogeneity analysis. Data transformation was included when data were not normally distributed. All tests were performed at the $5 \%$ level of significance.

\section{Results and discussion}

\subsection{Characteristics of AgNPs}

The SPR curves (Fig. 1a) show well-defined absorptions peaks at 406 (T-AgNP), 400 (E-AgNP) and $414 \mathrm{~nm}$ (C-AgNP) that indicate the presence of AgNPs [4, 19, 76, $82,97]$. These peaks were absent in controls containing media, pure coating material and coating material plus $\mathrm{KOH}$. The secondary peaks of SPR spectra at 272 (T-AgNP), 270 (E-AgNP) and $256 \mathrm{~nm}$ (C-AgNP) are due to the Ag-bound tyrosine [43, 82], EGCG [87] and curcumin molecules [75], respectively. The TEM images (Fig. 1b-d) further confirm the presence of spherical NPs. The mean core sizes obtained by analysing 50-150 particles from ImageJ software analysis and the HDD obtained by DLS measurements are shown in Table 1 . The mean size of NPs indicates that they may be considered approximately same diameter for the purpose of investigations performed in this study. The histogram (Fig. S.2) indicates a wide distribution of core particle sizes with few approaching up to approximately $40 \mathrm{~nm}$ in diameter. The size measured by the DLS technique is the HDD of the theoretical sphere of the NPs which is influenced by the substances adsorbed onto the NPs. Bigger HDD values obtained from DLS than the sizes obtained by TEM images for the NPs used in this study (Table 1) suggest the presence of coatings on AgNPs [95] while zeta potential values below $-30 \mathrm{mV}$ suggests strong bonding of organic molecules on AgNP surface [20]. However, the value of the shell thickness calculated for T-AgNPs, E-AgNPs and C-AgNPs (approximately 41, 31 and $23 \mathrm{~nm}$, respectively) is contradictory to the smaller shell thickness visible in the TEM images. The $z$-average is the intensity weighted mean hydrodynamic size of particles. The intensity-based data are biased towards larger particles shifting the $z$-average towards larger values [89]. Larger $z$-average values observed for AgNPs in this study may be because of aggregates formed by interaction between molecules adsorbed onto nanoparticles surface. However, the forces between nanoparticles in the aggregates are not so strong in this case, and therefore, the aggregates are not visible in TEM images after sample preparation. The concentrations of T-AgNP, E-AgNP, C-AgNP and $\mathrm{Ag}_{2} \mathrm{SO}_{4}$ stock solutions were 45.59, $48.84,42.66$ and $10.52 \mathrm{mg} \mathrm{L}^{-1}$, respectively.

\subsection{AgNP stability and dissolution}

AgNP suspensions in algae medium were initially yellowish in colour with absorption peaks of T-AgNPs, E-AgNPs 
Fig. 1 a The SPR of AgNPs in MilliQ water. TEM images of b T-AgNPs, c E-AgNPs, and d C-AgNPs
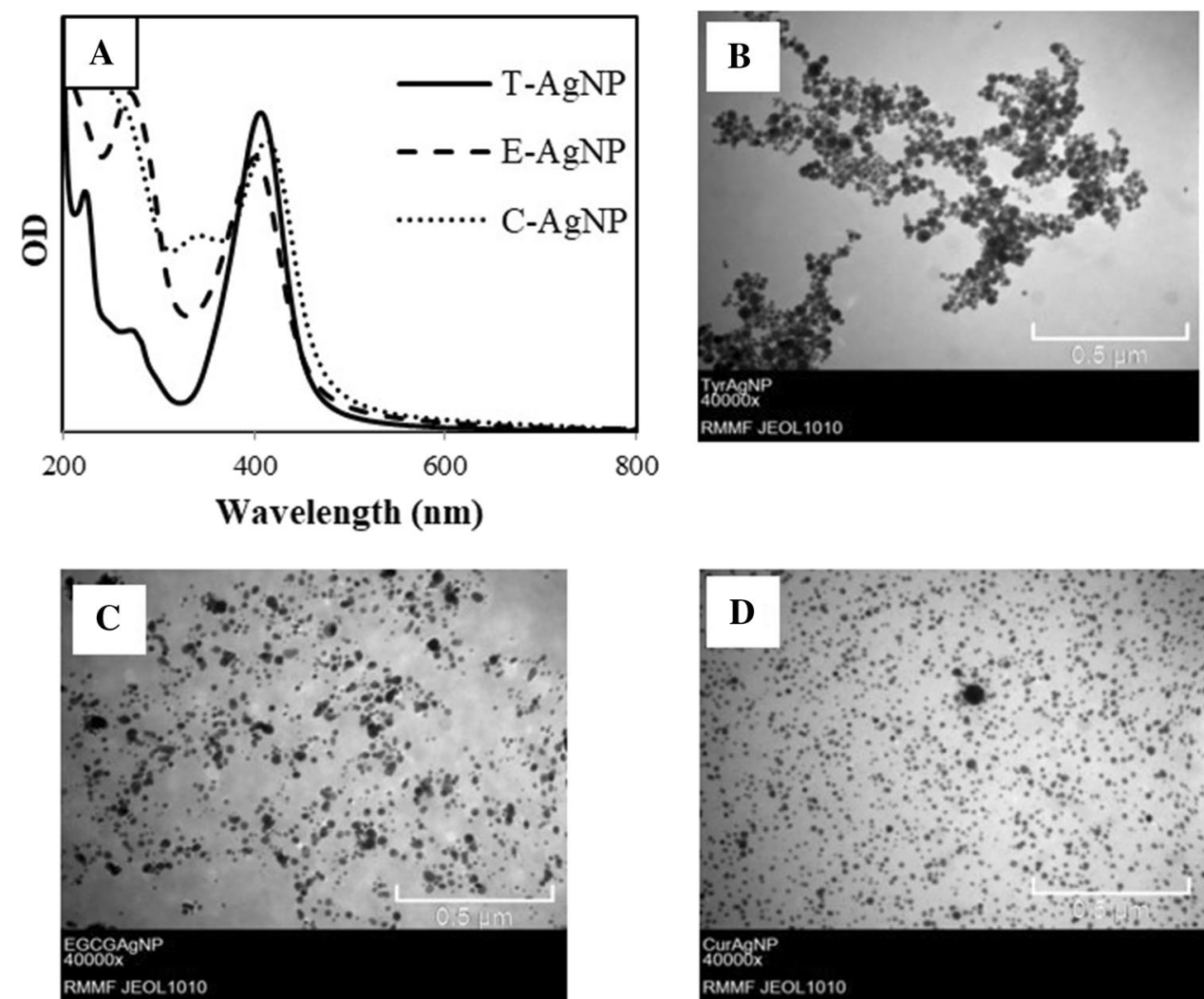

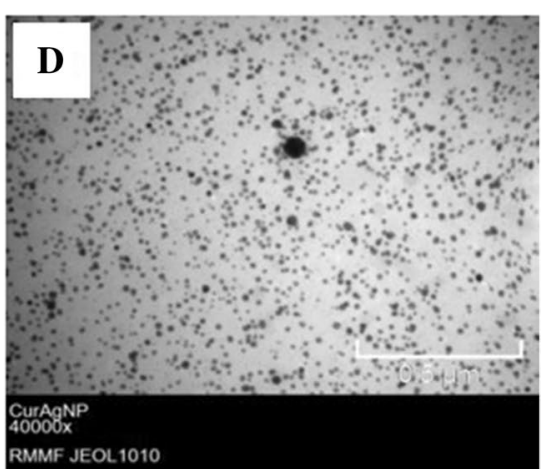

Table 1 Summary of AgNP sizes and zeta potential in MilliQ water

\begin{tabular}{lrrr}
\hline & \multicolumn{1}{l}{ T-AgNP } & \multicolumn{1}{l}{ E-AgNP } & \multicolumn{1}{l}{ C-AgNP } \\
\hline HDD & $51.58 \pm 0.55$ & $40.06 \pm 1.50$ & $36.37 \pm 0.58$ \\
TEM average size & $10.56 \pm 2.27$ & $9.27 \pm 1.29$ & $13.68 \pm 0.76$ \\
$\quad(\mathrm{~nm})$ & & & \\
Zeta potential $(\mathrm{mV})$ & $-42.13 \pm 0.33$ & $-38.93 \pm 1.37$ & $-44.65 \pm 1.65$ \\
\hline
\end{tabular}

and C-AgNPs were at 406, 400 and $414 \mathrm{~nm}$, respectively. E-AgNP suspension turned to yellowish red within minutes, but the colour of T-AgNP and C-AgNP was stable even after $72 \mathrm{~h}$. Absorption peaks of T-AgNP and E-AgNP SPR spectra decreased by $32 \%$ compared with only $10 \%$ decrease in C-AgNPs (Fig. 2). The plasmon bands of E-AgNPs broadened, a shoulder appeared for both T-AgNPs and E-AgNPs, but no changes were observed for C-AgNPs. The mean HDD of T-AgNPs increased approximately by 1.5 while no significant increase was observed for E-AgNPs and C-AgNPs (Table 2). Further, polydispersity index of both T-AgNPs and E-AgNPs did not change significantly. However, the distribution analysis of DLS results from standard reports revealed that the percentage fractions of T-AgNPs and E-AgNPs with sizes over $100 \mathrm{~nm}$ have increased by $8 \%$ and $29 \%$, respectively. Therefore, it is required to be very careful in interpreting the results obtained from DLS technique. Further, it is recommended to use other reliable techniques as well such as atomic force microscopy (AFM) and TEM to comprehensively study the stability of NPs. The zeta potential for all the particles increased instantly but remained close to $-30 \mathrm{mV}$ thereafter (Table 2). The percentage dissolution of $\mathrm{Ag}^{+}$ions from T-AgNPs and E-AgNPs was below $0.5 \%$ in algae medium within the test duration while it was approximately $1.5 \%$ for C-AgNPs by the end of $72 \mathrm{~h}$.

A broader absorbance peak, large background signal and increased HDD indicate aggregation of NPs $[90,94]$. As per the SPR and HDD results, aggregation in the M4 medium was highest for T-AgNPs followed by E-AgNPs while C-AgNPs showed no signs of aggregation. Aggregation of NPs depends on particle concentration, $\mathrm{pH}$, ionic strength, ionic composition, concentration and composition of natural organic matter, and other characteristics of the aqueous media $[53,104]$. Since these parameters are not considerably different, it can be suggested that the observed differences in destabilization was due to different coating materials [68]. Influence of coating materials of NPs on their stability is reported elsewhere $[10,51,94]$. The colour, SPR peak (Fig. S.3A-C), HDD (Table S.1) and Zeta potential (Table S.1) of all three types of NP suspensions in MilliQ water remained largely unchanged. Less aggregation of NPs in MilliQ water, but not in the M4 medium could be attributed to the higher ionic strength of the 

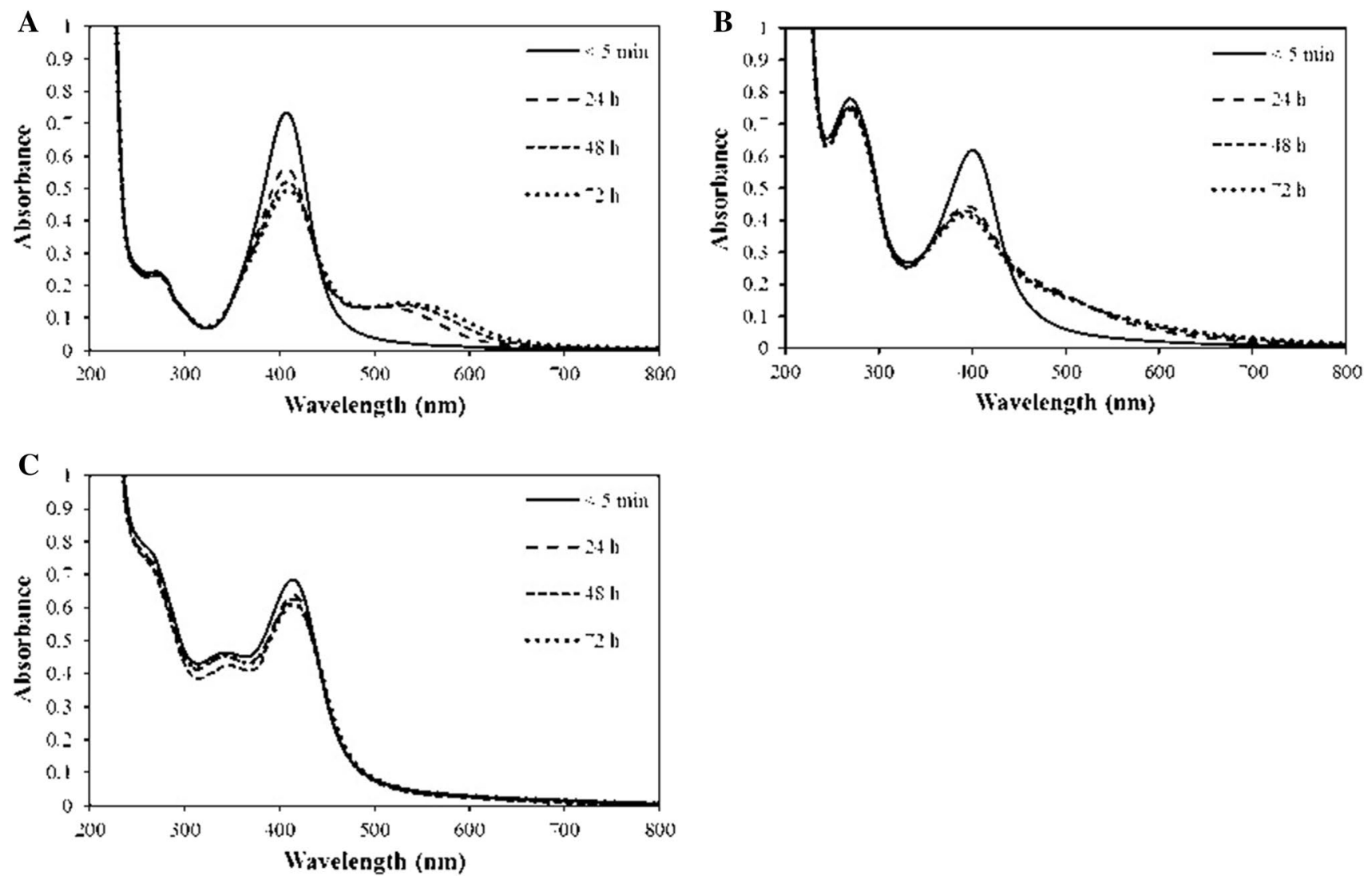

Fig. 2 The SPR curves of a T-AgNPs, b E-AgNPs, and c C-AgNPs in M4 medium

Table 2 HDD, zeta potential, polydispersity index (Pdi) and dissolution of AgNPs with different coatings in M4 medium measured at different times within the test duration

\begin{tabular}{|c|c|c|c|c|c|c|c|c|c|}
\hline \multirow[t]{2}{*}{ Substance } & \multicolumn{2}{|l|}{$\mathrm{HDD}(\mathrm{nm})$} & \multicolumn{2}{|c|}{ Zeta potential (mV) } & \multicolumn{2}{|l|}{ Pdl } & \multicolumn{3}{|c|}{$\%$ Dissolution } \\
\hline & $<5 \min$ & $72 \mathrm{~h}$ & $<5 \min$ & $72 \mathrm{~h}$ & $<5 \min$ & $72 \mathrm{~h}$ & $24 \mathrm{~h}$ & $48 \mathrm{~h}$ & $72 \mathrm{~h}$ \\
\hline T-AgNP & $50.4 \pm 7.1$ & $75.1 \pm 4.8$ & $-29.7 \pm 1.7$ & $-30.7 \pm 1.1$ & $0.37 \pm 0.08$ & $0.45 \pm 0.01$ & $0.06 \pm 0.14$ & $0.15 \pm 0.11$ & $0.25 \pm 0.09$ \\
\hline E-AgNP & $40.1 \pm 10.3$ & $51.1 \pm 2.6$ & $-30.8 \pm 1.1$ & $-29.8 \pm 2.3$ & $0.58 \pm 0.09$ & $0.52 \pm 0.10$ & $0.16 \pm 0.26$ & $0.06 \pm 0.21$ & $0.22 \pm 0.02$ \\
\hline C-AgNP & $45.0 \pm 3.8$ & $48.9 \pm 2.2$ & $-29.0 \pm 2.1$ & $-31.0 \pm 1.6$ & $0.42 \pm 0.02$ & $0.42 \pm 0.07$ & $0.66 \pm 0.81$ & $1.36 \pm 0.58$ & $1.39 \pm 0.61$ \\
\hline
\end{tabular}

NPs were dispersed in the media at Ag concentration of $5 \mathrm{mg} \mathrm{L}^{-1}$. Standard deviations ( \pm SD) are from triplicates. See Table S.1 for relevant data in MilliQ water

medium. However, the dissolution of all types of AgNPs was slightly higher in MilliQ water (Table S.1) than in the algae medium. This may be due to the precipitation of $\mathrm{Ag}$ ions by halides $\left(\mathrm{Cl}^{-}\right)$in the medium $[30,77]$ leaving less detectable ions in the solution. Halides may reduce the exposure of organisms to any free ions released from NPs. Also, MilliQ water was slightly acidic ( $\mathrm{pH}: 6.44)$ compared to media which may have caused higher oxidation of AgNPs releasing more $\mathrm{Ag}^{+}$ions into the solution [107]. The dissolution experiments were conducted using AgNP concentrations which were 1-3 orders of magnitude higher than the concentrations used in the experiment. $\mathrm{Ag}^{+}$ion release kinetics tend to level off at higher concentrations, but this possibility was excluded since the observed dissolved ion concentrations were marginal. However, studies have shown that far higher percentages of $\mathrm{Ag}^{+}$ion release are commonly observed at low concentrations as a function of time. Therefore, the percentage $\mathrm{Ag}^{+}$ions released from the NPs in tests vials may be higher than the values presented.

The behaviour of NPs in test systems is not predictable using the traditional methods of partitioning and bioavailability $[22,66]$. The stability of organic-coated AgNPs in biological media has received significant 
attention in the last few years in nanotechnology and toxicology studies $[3,84]$. Similar to the observations made in this study, other toxicological studies also have shown that aggregation, dissolution, change in NP characteristics and culture media influence the bioavailability of NPs and hence, play an important role in determining toxicity $[37,86,106]$. Therefore, it is required to consider those factors when performing toxicity assessments.
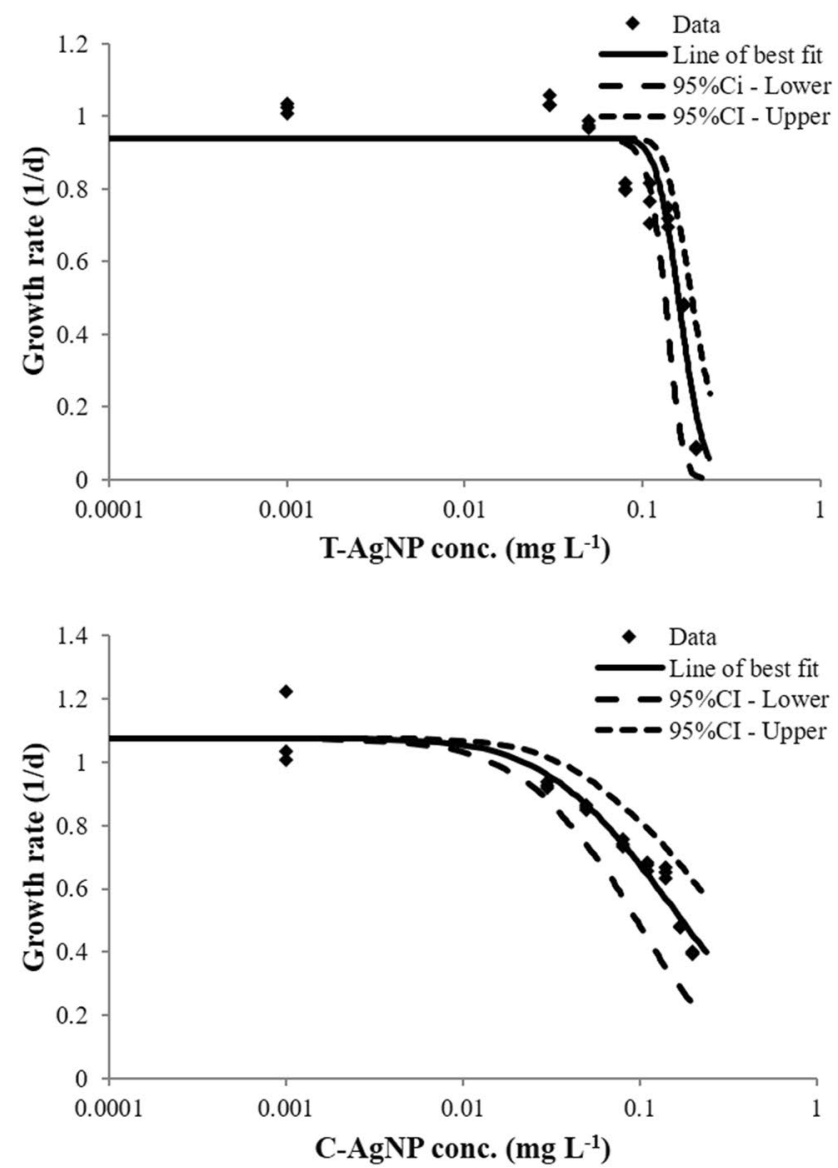

\subsection{Algal toxicity of $\mathrm{AgNPs}$ and $\mathrm{Ag}^{+}$ions}

Concentration-effect curves (Fig. 3 ) show that the average specific growth rates decreased with increasing concentration of all three types of NPs and $\mathrm{Ag}^{+}$ions indicating that the toxicity positively correlated to the concentration. Also, a time-dependent effect was observed for all three type of AgNPs and $\mathrm{Ag}^{+}$ions at all concentrations since the differences between growth rates of algae in exposed groups decreased compared with control groups during $72 \mathrm{~h}$ of exposure period. The $72 \mathrm{~h} \mathrm{EC}{ }_{10}, \mathrm{EC}_{20}$ and $\mathrm{EC}_{50}$ values
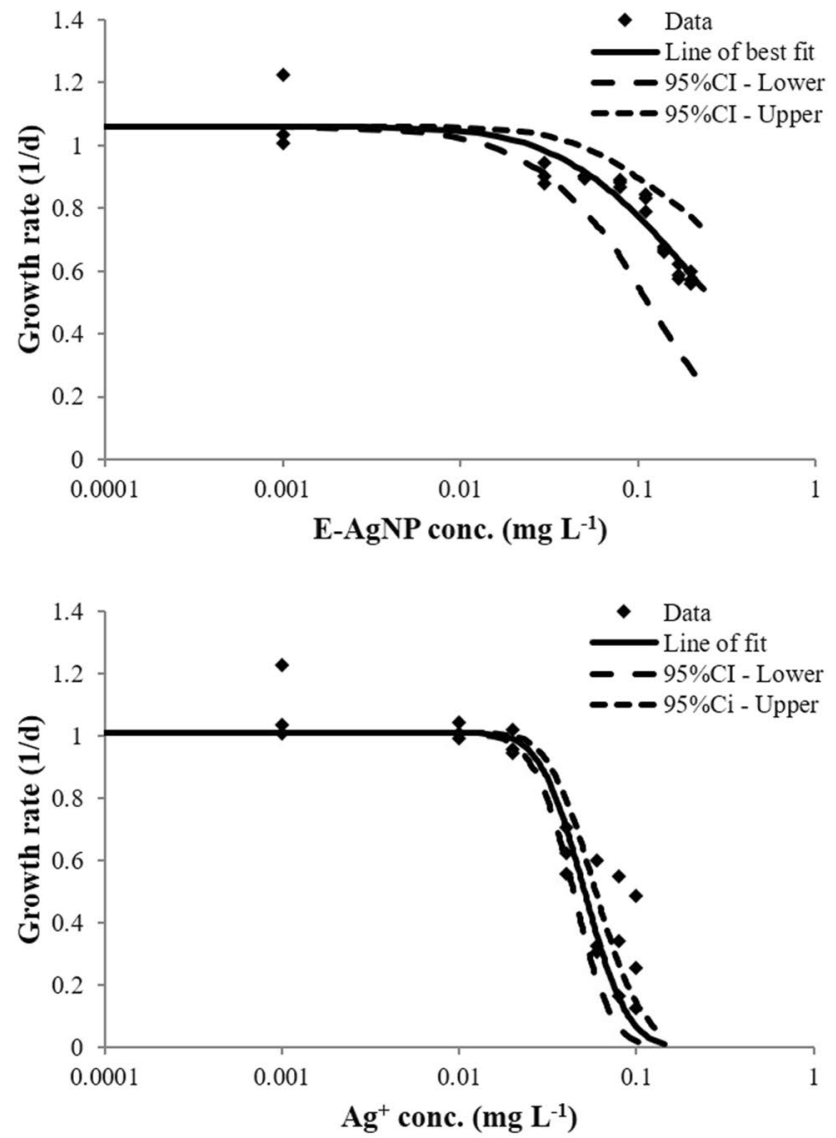

Fig. 3 Concentration-effect curves showing the influence of AgNPs with different coatings and Ag + on growth rate of the introduced Raphidocelis subcapitata as observed from 0 to $72 \mathrm{~h}$

Table 3 The toxicity of AgNPs with different coatings and $\mathrm{Ag}^{+}$ions to algae Raphidocelis subcapitata (Based on 72-h growth inhibition)

\begin{tabular}{|c|c|c|c|c|c|c|c|c|c|}
\hline \multirow[t]{2}{*}{ Substance } & \multicolumn{3}{|l|}{$\mathrm{EC}_{50}$} & \multicolumn{3}{|l|}{$\mathrm{EC}_{20}$} & \multicolumn{3}{|l|}{$\mathrm{EC}_{10}$} \\
\hline & \multirow{2}{*}{$\begin{array}{l}\mathrm{mg} \mathrm{L}^{-1} \\
0.051\end{array}$} & \multicolumn{2}{|c|}{$\begin{array}{l}95 \% \text { confidence } \\
\text { interval }\end{array}$} & \multirow{2}{*}{$\begin{array}{l}\mathrm{mg} \mathrm{L}^{-1} \\
0.035\end{array}$} & \multicolumn{2}{|c|}{$\begin{array}{l}95 \% \text { confidence } \\
\text { interval }\end{array}$} & \multirow{2}{*}{$\begin{array}{c}\mathrm{mg} \mathrm{L}^{-1} \\
0.031\end{array}$} & \multicolumn{2}{|c|}{$\begin{array}{l}95 \% \\
\text { confidence } \\
\text { interval }\end{array}$} \\
\hline $\mathrm{Ag}^{+}$ions & & 0.044 & 0.059 & & 0.035 & 0.039 & & 0.025 & 0.032 \\
\hline T-AgNP & 0.163 & 0.136 & 0.194 & 0.133 & 0.115 & 0.153 & 0.119 & 0.103 & 0.138 \\
\hline E-AgNP & 0.243 & 0.105 & 0.538 & 0.072 & 0.039 & 0.133 & 0.038 & 0.022 & 0.07 \\
\hline C-AgNP & 0.155 & 0.088 & 0.271 & 0.051 & 0.033 & 0.081 & 0.029 & 0.018 & 0.045 \\
\hline
\end{tabular}


which were calculated based on the percentage inhibition of growth of alga upon exposure to AgNPs and $\mathrm{Ag}^{+}$ ions are shown in Table 3. Among the three coated AgNPs, toxicity of C-AgNPs and T-AgNPs $\left(72 \mathrm{~h} \mathrm{EC}_{50}: 0.155\right.$ and $0.163 \mathrm{mg} \mathrm{L}^{-1}$ ) were not significantly different and caused the highest toxicity while E-AgNPs were the least toxic (72 $\mathrm{h} \mathrm{EC}_{50}: 0.243 \mathrm{mg} \mathrm{L}^{-1}$ ). However, $\mathrm{EC}_{20}$ and $\mathrm{EC}_{10}$ values of T-AgNPs (133 and $119 \mu \mathrm{g} \mathrm{L}^{-1}$ ) were considerably higher than both E-AgNPs $\left(0.072\right.$ and $\left.0.038 \mathrm{mg} \mathrm{L}^{-1}\right)$ and C-AgNPs $\left(0.033\right.$ and $\left.0.029 \mathrm{mg} \mathrm{L}^{-1}\right)$. Although there was no difference between the toxicity of T-AgNPs and C-AgNPs based on $\mathrm{EC}_{50}$ values, this demonstrates that the toxicity of T-AgNPs increased rapidly with increased concentrations; the percentage of viable cells compared to the control at the highest concentration tested $\left(0.2 \mathrm{mg} \mathrm{L}^{-1}\right)$ was only $6 \%$ for T-AgNPs in comparison with 15.3 and $26.3 \%$ for C-AgNPs and E-AgNPs, respectively, confirming that the toxicity of AgNP is in the order of T-AgNP > C-AgNP > E-AgNP. The toxicity of AgNPs to freshwater algae has been examined in several studies and the values obtained in the present study are consistent with the reported $\mathrm{EC}_{50}$ values which are ranging from 0.008 to $1.2 \mathrm{mg} \mathrm{L}^{-1}[39,44,50,74,88]$. However, the toxicity of $\mathrm{Ag}^{+}$ions observed $\left(72 \mathrm{~h} \mathrm{EC}_{50}\right.$ : $0.051 \mathrm{mg} \mathrm{L}^{-1}$ ) was less than the reported values, ranging from 0.005 to $0.034 \mathrm{mg} \mathrm{L}^{-1}[39,50,74,88]$. This may be due to the source of $\mathrm{Ag}^{+}$ions in the current study was $\mathrm{Ag}_{2} \mathrm{SO}_{4}$ instead of $\mathrm{AgNO}_{3}$ which was the preferred source of $\mathrm{Ag}^{+}$ ions in other studies and $\mathrm{AgNO}_{3}$ may be more toxic to algae than $\mathrm{Ag}_{2} \mathrm{SO}_{4}$.

Most previous studies reported that the nano form of $\mathrm{Ag}$ was less toxic in comparison with their ionic counterparts ( $\mathrm{Ag}^{+}$ions) [62]; it is likely that the liberated ions from the NPs cause toxicity $[28,70,102,103]$. In the present study, the $\mathrm{EC}_{50}$ value $(72 \mathrm{~h})$ of $\mathrm{Ag}^{+}$ions $\left(0.051 \mathrm{mg} \mathrm{L}^{-1}\right)$ observed is significantly lower than the $\mathrm{EC}_{50}$ values of the AgNPs which suggests that the tested coated AgNPs are less toxic than $\mathrm{Ag}^{+}$ions. However, interestingly, the $\mathrm{EC}_{10}$ of $\mathrm{Ag}^{+}$ions (0.029 $\mathrm{mg} \mathrm{L}^{-1}$ ) and C-AgNPs (0.029 $\left.\mathrm{mg} \mathrm{L}^{-1}\right)$ were similar along with the $\mathrm{EC}_{50}$ values of E-AgNPs (0.038 $\mathrm{mg} \mathrm{L}^{-1}$ ). Ribeiro et al. [74] exposed $R$. subcapitata to alkane-coated AgNPs (size $<10 \mathrm{~nm}$ ) and $\mathrm{Ag}^{+}$ions and observed that AgNPs were twice as toxic as $\mathrm{Ag}^{+}$ions at concentrations of $0.025 \mathrm{mg} \mathrm{L}^{-1}$. Further, Navarro et al. [61] reported that the toxicity of AgNPs were much higher than that of the $\mathrm{Ag}^{+}$ions to Chlamydomonas reinhardtii when compared as a function of $\mathrm{Ag}^{+}$ions, since the free $\mathrm{Ag}^{+}$ ions from AgNPs in the medium could not fully explain the toxicity. In the present study, the $\mathrm{EC}_{50}$ values calculated (data not shown) as a function of $\mathrm{Ag}^{+}$ion concentrations (by using the percentage dissolution values) for all three types of NP concentrations used are far below the $\mathrm{EC}_{50}$ value obtained for $\mathrm{Ag}^{+}$ions $\left(\mathrm{Ag}_{2} \mathrm{SO}_{4}\right)$. Also, $\mathrm{Ag}^{+}$ ions liberated from NPs may be precipitated by the halides in the culture medium causing less concentration of $\mathrm{Ag}^{+}$ ions than predicted by using the percentage dissolution values obtained from dissolution experiments. Therefore, the toxicity caused by liberated ions from all three types of AgNPs is considerably less, and therefore, the observed toxicity of AgNPs to alga in this study is mainly attributed to the particle effects rather than from $\mathrm{Ag}^{+}$ions.

The unicellular algae $R$. subcapitata was selected for the experimental analysis since it is a popular alga species in ecotoxicology due to its wide availability, ease of culture, ecological relevance and high sensitivity to contaminants. It is used as a model organism in the OECD algal growth inhibition test [63] and in other regulatory agencies worldwide. Algal growth inhibition at the exponential growth stage is the most frequent criterion used to evaluate toxicity. Growth inhibition is inferred in terms of change of biomass which is determined by cell count, chlorophyll a measurement or dry weight [40]. MLA medium [11,99] was selected for the study since it was highly effective for culturing the particular alga in our lab in comparison with the Hoagland and standard OECD algae growth medium. Aruoja et al. [8] assessed the effects of shading by NPs on the performance of algae and concluded that the shading effect from NPs was negligible. The NP concentrations they used were three orders of magnitude higher than the concentrations used in this study, and therefore, it was assumed that shading from NPs had no effect on the results obtained. Quantification of algae cells in tests was done by measuring the in vivo chlorophyll fluorescence (POLARstar omega, BMG LABTECH) which proved highly effective. Automated cell counting $\left(\mathrm{TC} 2 \mathrm{O}^{\mathrm{TM}}\right.$ Automated Cell Counter, Bio-Rad Laboratories, Hercules, CA) was effective with viable cells, but gave unrealistic readings in the presence of dead cells, especially when samples treated with higher concentrations of highly toxic $\mathrm{Ag}^{+}$ions were measured. The suitability of the fluorometric method for quantification of algae cells was demonstrated in a previous study conducted by Eisentraeger et al. [26] and used by several researchers $[8,35]$.

\subsection{Associated AgNPs and $\mathrm{Ag}^{+}$ions}

The associated Ag contents in algae against the concentration of AgNPs and $\mathrm{Ag}^{+}$ions are shown in Fig. $4 \mathrm{a}, \mathrm{b}$, respectively. The results demonstrate that the associated Ag quantity increases with increased concentrations for both $\mathrm{Ag} \mathrm{NPs}$ and $\mathrm{Ag}^{+}$ions. However, the $\mathrm{Ag}$ accumulation in algal cells exposed to $\mathrm{Ag}^{+}$ions is comparatively higher than the Ag NPs while the $\mathrm{Ag}_{\text {cell }}$ was approximately 6.5 times higher in the algal cells exposed to $\mathrm{Ag}^{+}$ions (0.1 $\mathrm{mg} \mathrm{L}^{-1}$ ) compared to C-AgNPs $\left(0.11 \mathrm{mg} \mathrm{L}^{-1}\right)$. A linear increase in $\mathrm{Ag}_{\text {cell }}$ was observed in the algal cells exposed to $\mathrm{Ag}^{+}$ions and $\mathrm{AgNPs}$ up to $0.14 \mathrm{mg} \mathrm{L}^{-1}\left(r^{2}\right.$ between 0.84 and 


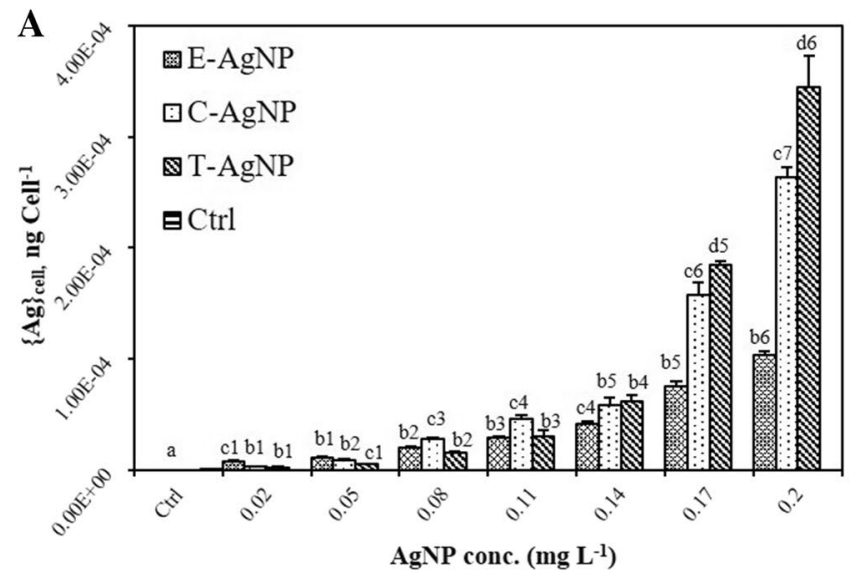

Fig. 4 Cell associated silver measured in Raphidocelis subcapitata after $72 \mathrm{~h}$ upon exposure to a AgNPs with different coatings, and b $\mathrm{Ag}^{+}$ions at different concentrations. The error bars indicate the SD $(p<0.05, n=3)$. Letter sign denotes comparison of $p$ values for

0.98 , respectively) while an exponential increase in $\mathrm{Ag}_{\text {cell }}$ was observed at higher ( 0.17 and $0.2 \mathrm{mg} \mathrm{L}^{-1}$ ) concentrations. Piccapietra et al. [67] found higher internalization of $\mathrm{Ag}$ in Chlamydomonas reinhardtii exposed to $\mathrm{Ag}^{+}$ions ( $\mathrm{AgNO}_{3}$ : 0.002-0.053 $\mathrm{mg} \mathrm{L}^{-1}$ ) compared to carbonatecoated AgNPs (AgNPs: 0.053-1.078 $\mathrm{mg} \mathrm{L}^{-1}$, size: $29 \mathrm{~nm}$ ) and the accumulation correlated with the concentration. They also observed a linear increase in $\mathrm{Ag}_{\text {cell }}$ in algae exposed to $\mathrm{Ag}^{+}$ions but not in the algae exposed to AgNPs where a constant accumulation level was observed at NP concentrations above $0.215 \mathrm{mg} \mathrm{L}^{-1}$. When the alga Euglena gracilis was exposed to AgNPs and $\mathrm{Ag}^{+}$ions, $\mathrm{Li}$ et al. [50] also observed a linear increase in $\mathrm{Ag}_{\text {cell }}$ in algae exposed to $\mathrm{Ag}^{+}$ions, but not for AgNPs where $\mathrm{Ag}_{\text {cell }}$ remained constant above the AgNP concentration of $0.269 \mathrm{mg} \mathrm{L}^{-1}$. Merdzan et al. [55] investigated the bioaccumulation of differently coated $\mathrm{ZnNPs}$ and $\mathrm{Zn}^{2+}$ ions in the alga C. reinhardtii and observed lower bioaccumulation of $\mathrm{Zn}$ from ZnNPs compared to Zn salt or bare ZnONPs which liberate more $\mathrm{Zn}^{2+}$ ions. Size of the pores and the change of permeability of cell wall limit the passage of silver through the cell wall [60], but not for ionic forms which can be explained by commonly accepted models including the free ion activity and biotic ligand models $[24,85]$. When compared with other studies, $\mathrm{Ag}_{\text {cell }}$ in AgNP-exposed algae cells in the present study did not reach a constant or steady state with increased concentration of AgNPs. This may be due to the maximum AgNP concentration tested in this study was $0.2 \mathrm{mg} \mathrm{L}^{-1}$ whereas others observed $\mathrm{Ag}_{\text {cell }}$ level became constant when the algae was exposed to AgNP concentrations above $0.2 \mathrm{mg} \mathrm{L}^{-1}$. We previously showed that $\mathrm{Ag}^{+}$ions were most toxic while E-AgNPs were least toxic. The highest associated Ag content was found in algae exposed to $\mathrm{Ag}^{+}$ions followed by T-AgNP, C-AgNP

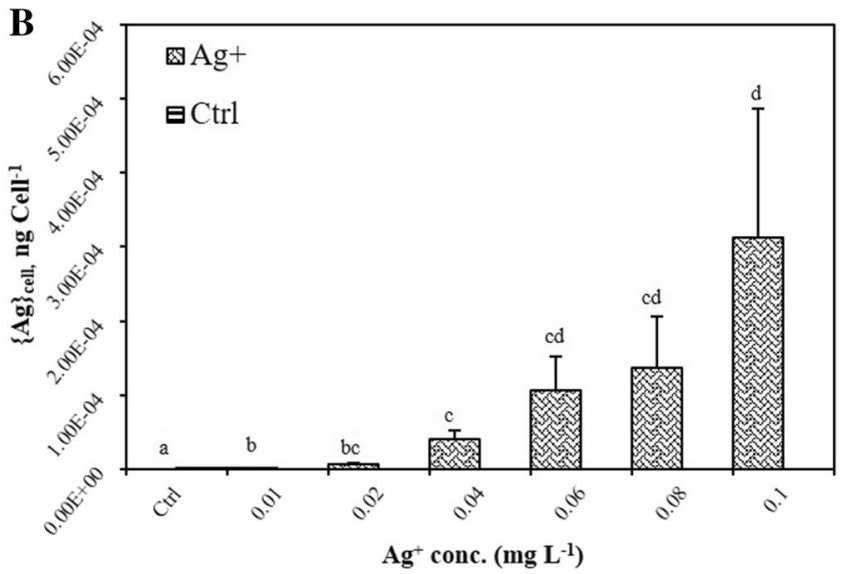

particles within each concentration and control while the number sign denotes comparison of $p$ values for each particle within different concentrations

and E-AgNPs. Therefore, it can be inferred that the toxicity correlates to the associated $\mathrm{Ag}$ content.

Difference in associated Ag content can be attributed to difference in bioavailability of NPs as suggested by Piccapietra et al. [67]. Further, it can be assumed that the type of coating of AgNPs used in this study influenced the bioavailability of AgNPs resulting in different uptake of AgNPs. However, data obtained from this study are insufficient to identify the reasons for the observed difference in uptake. Metallic NPs may cause toxicity to algae by ions released from NPs while they are in the suspension, attached to the surface of cells or after internalization $[25,56]$. However, toxicity of NPs other than from released ions have been reported [56]. The coatings of AgNPs used in this study considerably reduced the dissolution of ions from AgNPs in suspension. The concentrations of $\mathrm{Ag}^{+}$ions released which were calculated based on percentage dissolution were well below the $\mathrm{EC}_{50}$ of $\mathrm{Ag}^{+}$ions observed. Therefore, the causes of toxicity could be attributed to the ions released from the associated AgNPs (surface attached or internalized) plus other adverse effects from AgNPs including physical damage. Associated Ag quantification was performed based on ICP-MS analysis after acid digestion. Any AgNPs associated with the algae would have been converted to $\mathrm{Ag}^{+}$ions with acid digestion. Therefore, from the results obtained, it is not possible to differentiate correct quantities of associated AgNPs from any $\mathrm{Ag}^{+}$ions released from NPs.

\subsection{Enzyme activity}

Increased activities of GST and CAT were found in alga upon exposure to AgNPs and $\mathrm{Ag}^{+}$ions at higher concentrations (Fig. 5). NPs induce ROS production $[6,25,54,65$, 


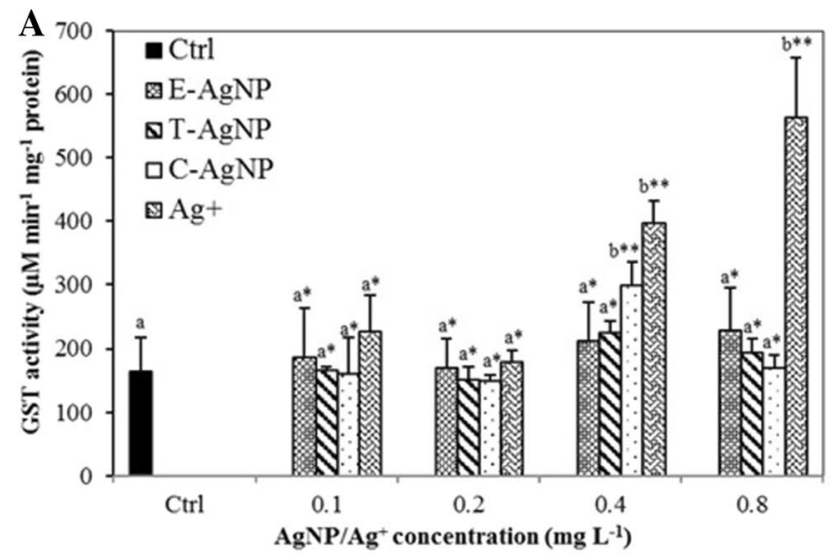

Fig. 5 Effect of AgNPs with different coatings and $\mathrm{Ag}^{+}$ions on antioxidant enzymes $\mathbf{a}$ GST, and $\mathbf{b}$ CAT activities of Raphidocelis Subcapitata after $72 \mathrm{~h}$ of exposure at different $\mathrm{AgNP}$ and $\mathrm{Ag}^{+}$ion concentrations. GST glutathione S-transferase, CAT catalase. The error bars

$100]$ and the upregulation of enzyme activities during exposure could be associated with increased production of ROS in the algae [21]. Generation of ROS inhibits algal growth and photosynthesis by damaging the cell membrane, nucleus and chloroplasts [21, 100]; the activity of some antioxidative enzymes are triggered in defence to protect from those negative effects [38]. CAT catalyses the dismutation of $\mathrm{H}_{2} \mathrm{O}_{2}$ to $\mathrm{H}_{2} \mathrm{O}$ and $\mathrm{O}_{2}$ while GST inactivates secondary metabolites such as lipid hydroperoxides in response to ROS [52] and is responsible for the repair of ROS oxidized macromolecules of damaged cellular components [7]. None of the AgNPs or $\mathrm{Ag}^{+}$ions caused increased activation of GST below $0.2 \mathrm{mg} \mathrm{L}^{-1}$ compared with the control while the activity was strongly triggered in algal cells exposed to $0.4 \mathrm{mg} \mathrm{L}^{-1}$ of C-AgNPs and 0.4 and $0.8 \mathrm{mg} \mathrm{L}^{-1}$ of $\mathrm{Ag}^{+}$ions. Also, the GST activation in algal cells exposed to $0.4 \mathrm{mg} \mathrm{L}^{-1}$ of C-AgNPs was significantly different to the cells exposed to same concentrations of T-AgNP and E-AgNP. CAT activity also was not significantly increased by AgNPs at concentrations below $0.2 \mathrm{mg} \mathrm{L}^{-1}$. However, an increased activation of CAT was observed in algae exposed to increased concentrations of T-AgNPs, E-AgNPs and $\mathrm{Ag}^{+}$ions $\left(0.4\right.$ and $0.8 \mathrm{mg} \mathrm{L}^{-1}$ ) compared with the control. C-AgNPs increased CAT activity only at $0.8 \mathrm{mg} \mathrm{L}^{-1}$ concentration though it caused significantly less activation of CAT levels compared with other types of NPs and $\mathrm{Ag}^{+}$ions within the same concentration group.

To date, the data regarding the effects of AgNPs on antioxidant activities in algae are scarce. However, increased GST and CAT activities were previously recorded after exposure to other NPs such as $\mathrm{TiO}_{2}$ NPs [21] and CuO NPs [54]. The activation of enzymes is different for AgNPs with different coatings and the toxicity may depend on the ability of the antioxidant system to activate the antioxidant

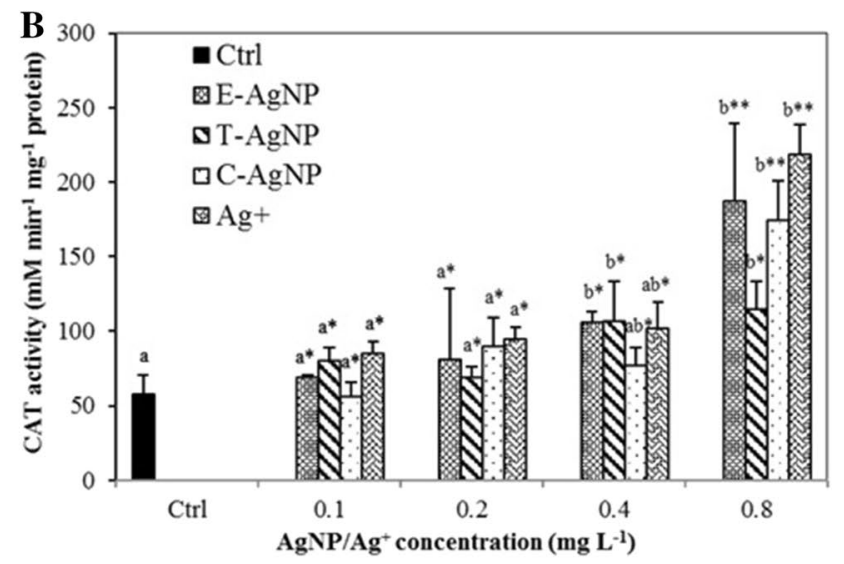

indicate the $\mathrm{SD}(p<0.05, n=3)$. Letter sign denotes comparison of $p$ values for particles within each concentration and control while the * sign denotes comparison of $p$ values between concentrations for each particle

enzymes at different concentrations of AgNPs with different surface functionalization. However, results from this study do not provide any strong basis for explaining the differential enzyme activation by differently coated AgNPs. Therefore, correlations between differently coated AgNPs and activation of antioxidant enzymes need further investigation. Also, the activation of antioxidant system is complex $[23,58]$ and the mechanisms of toxicity of each type of differently coated AgNPs on algae may be equally complex $[15,56]$. Therefore, it is difficult to explain the cause of the differential toxicity of differently coated AgNPs by the response of tested enzymes activities, and thus, it is required to evaluate the responses of suit of antioxidant enzymes to fully explain the different toxic effects.

\section{Conclusion}

This study shows that the physicochemical characteristics of the surface coatings of AgNPs play a major role in determining their behaviour in the algae growth medium, the toxicity, bioaccumulation and antioxidant enzyme responses of algae. T-AgNPs seemed less stable compared with E-AgNPs and C-AgNPs though all three types of NPs remained quite stable in the 72-h test duration. The highest toxicity to algae was caused by ionic silver followed by C-AgNPs, T-AgNPs, and E-AgNPs, respectively. The results clearly showed that toxicity increased with the concentration of $\mathrm{Ag}^{+}$and AgNPs; the associated Ag content in algae followed the same pattern. Increased GST and CAT levels indicate increased antioxidant activity in response to possible $\mathrm{ROS}$ production caused by AgNPs and $\mathrm{Ag}^{+}$ions. Taken together, these findings indicate that AgNPs pose ecological risk to aquatic organisms depending on the 
inherent characteristics of the NP and surrounding environment. Therefore, these factors should be considered in environmental risk assessment of AgNPs. In addition, the sensitivity of algae varies with differently functionalized AgNPs; further studies are recommended to understand the influence of different coatings on the toxicity of AgNPs to primary producers in aquatic ecosystems.

Acknowledgements The authors acknowledge the support from the RMIT Microscopy and Microanalysis Facility (RMMF) for technical assistance and providing access to characterization facilities. We furthermore acknowledge Mr. Paul. D. Morrison at the Australian Centre for Research on Separation Science, School of Applied Sciences, RMIT University for technical assistance provided in ICP-MS sample analysis.

\section{Compliance with ethical standards}

Conflict of interest On behalf of all authors, the corresponding author states that there is no conflict of interest.

Ethical approval All applicable international, national, and/or institutional guidelines for the care and use of animals were followed. This article does not contain any studies with human participants performed by any of the authors.

\section{References}

1. Abramenko N, Demidova T, Krutyakov YA, Zherebin P, Krysanov E, Kustov L, Peijnenburg W (2019) The effect of capping agents on the toxicity of silver nanoparticles to Danio rerio embryos. Nanotoxicology 13:1-13

2. Aebi H (1984) Catalase in vitro. Methods Enzymol 105:121-126

3. Afshinnia K, Marrone B, Baalousha M (2018) Potential impact of natural organic ligands on the colloidal stability of silver nanoparticles. Sci Total Environ 625:1518-1526

4. Ahmad N, Sharma S, Alam MK, Singh V, Shamsi S, Mehta B, Fatma A (2010) Rapid synthesis of silver nanoparticles using dried medicinal plant of basil. Colloids Surf B 81:81-86

5. Akter M, Sikder MT, Rahman MM, Ullah AA, Hossain KFB, Banik S, Hosokawa T, Saito T, Kurasaki M (2018) A systematic review on silver nanoparticles-induced cytotoxicity: physicochemical properties and perspectives. J Adv Res 9:1-16

6. Angel BM, Vallotton P, Apte SE (2015) On the mechanism of nanoparticulate $\mathrm{CeO}_{2}$ toxicity to freshwater algae. Aquat Toxicol 168:90-97

7. Angelucci F, Baiocco P, Brunori M, Gourlay L, Morea V, Bellelli A (2005) Insights into the catalytic mechanism of glutathione s-transferase: the lesson from Schistosoma haematobium. Structure 13:1241-1246

8. Aruoja V, Dubourguier H-C, Kasemets K, Kahru A (2009) Toxicity of nanoparticles of $\mathrm{CuO}, \mathrm{ZnO}$ and $\mathrm{TiO}_{2}$ to microalgae Pseudokirchneriella subcapitata. Sci Total Environ 407:1461-1468

9. Barbero CA, Yslas El (2017) Ecotoxicity effects of nanomaterials on aquatic organisms: nanotoxicology of materials on aquatic organisms. In: Applying nanotechnology for environmental sustainability. IGI Global, pp 330-351

10. Baumann J, Köser J, Arndt D, Filser J (2014) The coating makes the difference: acute effects of iron oxide nanoparticles on Daphnia magna. Sci Total Environ 484:176-184
11. Bolch CJS, Blackburn SI (1996) Isolation and purification of Australian isolates of the toxic cyanobacterium Microcystis aeruginosa Kütz. J Appl Phycol 8:5-13

12. Briffa S, Nasser F, Valsami-Jones E, Lynch I (2018) Uptake and impacts of polyvinylpyrrolidone (PVP) capped metal oxide nanoparticles on Daphnia magna: role of core composition and acquired corona. Environ Sci Nano 5:1745-1756

13. Bundschuh M, Filser J, Lüderwald S, Mckee MS, Metreveli G, Schaumann GE, Schulz R, Wagner S (2018) Nanoparticles in the environment: where do we come from, where do we go to? Environ Sci Europe 30:6

14. Burdușel A-C, Gherasim O, Grumezescu A, Mogoantă L, Ficai A, Andronescu E (2018) Biomedical applications of silver nanoparticles: an up-to-date overview. Nanomaterials 8:681

15. Chang Y-N, Zhang M, Xia L, Zhang J, Xing G (2012) The toxic effects and mechanisms of $\mathrm{CuO}$ and $\mathrm{ZnO}$ nanoparticles. Materials 5:2850-2871

16. Clément L, Hurel C, Marmier N (2013) Toxicity of $\mathrm{TiO}_{2}$ nanoparticles to cladocerans, algae, rotifers and plants-effects of size and crystalline structure. Chemosphere 90:1083-1090

17. Contino A, Maccarrone G, Zimbone M, Reitano R, Musumeci P, Calcagno L, Oliveri IP (2016) Tyrosine capped silver nanoparticles: a new fluorescent sensor for the quantitative determination of copper(II) and cobalt(II) ions. J Colloid Interface Sci 462:216-222

18. Crenier C, Sanchez-Thirion K, Bec A, Felten V, Ferriol J, Gonzalez AG, Leflaive J, Perriere F, Ten-Hage L, Danger M (2019) Interactive impacts of silver and phosphorus on autotrophic biofilm elemental and biochemical quality for a macroinvertebrate consumer. Front Microbiol 10:732

19. Cruz D, Falé PL, Mourato A, Vaz PD, Luisa Serralheiro M, Lino ARL (2010) Preparation and physicochemical characterization of Ag nanoparticles biosynthesized by Lippia citriodora (Lemon Verbena). Colloids Surf B 81:67-73

20. Daima HK, Selvakannan P, Kandjani AE, Shukla R, Bhargava SK, Bansal V (2014) Synergistic influence of polyoxometalate surface corona towards enhancing the antibacterial performance of tyrosine-capped Ag nanoparticles. Nanoscale 6:758-765

21. Dauda S, Chia MA, Bako SP (2017) Toxicity of titanium dioxide nanoparticles to Chlorella vulgaris Beyerinck (Beijerinck) 1890 (Trebouxiophyceae, Chlorophyta) under changing nitrogen conditions. Aquat Toxicol 187:108-114

22. de Souza TAJ, Souza LRR, Franchi LP (2019) Silver nanoparticles: an integrated view of green synthesis methods, transformation in the environment, and toxicity. Ecotoxicol Environ Saf 171:691-700

23. Dewez D, Geoffroy L, Vernet G, Popovic R (2005) Determination of photosynthetic and enzymatic biomarkers sensitivity used to evaluate toxic effects of copper and fludioxonil in alga Scenedesmus obliquus. Aquat Toxicol 74:150-159

24. di Toro DM, Allen HE, Bergman HL, Meyer JS, Paquin PR, Santore RC (2001) Biotic ligand model of the acute toxicity of metals. 1. Technical basis. Environ Toxicol Chem 20:2383-2396

25. Domingo G, Bracale M, Vannini C (2019) Phytotoxicity of silver nanoparticles to aquatic plants, algae, and microorganisms. In: Nanomaterials in plants, algae and microorganisms. Elsevier, pp 143-168

26. Eisentraeger A, Dott W, Klein J, Hahn S (2003) Comparative studies on algal toxicity testing using fluorometric microplate and Erlenmeyer flask growth-inhibition assays. Ecotoxicol Environ Saf 54:346-354

27. El Khoury E, Abiad M, Kassaify ZG, Patra D (2015) Green synthesis of curcumin conjugated nanosilver for the applications in nucleic acid sensing and anti-bacterial activity. Colloids Surf B 127:274-280 
28. Franklin NM, Rogers NJ, Apte SC, Batley GE, Gadd GE, Casey PS (2007) Comparative toxicity of nanoparticulate $\mathrm{ZnO}$, bulk $\mathrm{ZnO}$, and $\mathrm{ZnCl}_{2}$ to a freshwater microalga (Pseudokirchneriella subcapitata): the importance of particle solubility. Environ Sci Technol 41:8484-8490

29. Frasco M, Guilhermino L (2002) Effects of dimethoate and beta-naphthoflavone on selected biomarkers of Poecilia reticulata. Fish Physiol Biochem 26:149-156

30. Garg S, Rong H, Miller CJ, Waite TD (2016) Oxidative dissolution of silver nanoparticles by chlorine: implications to silver nanoparticle fate and toxicity. Environ Sci Technol 50:3890-3896

31. Gorka DE, Gorham JM (2018) Physical and chemical transformations of silver nanomaterial-containing textiles after use. Biotech Biomater Miomed TechConnect Br 2018:154-157

32. Grandviewresearch (2015) Global silver nanoparticles market by application. http://www.grandviewresearch.com/indus try-analysis/silver-nanoparticles-market. Accessed 12 July 2017

33. Gupta K, Chhibber S (2019) Biofunctionalization of silver nanoparticles with lactonase leads to altered antimicrobial and cytotoxic properties. Front Mol Biosci 6:63

34. Habig WH, Pabst MJ, Jakoby WB (1974) Glutathione S-transferases the first enzymatic step in mercapturic acid formation. J Biol Chem 249:7130-7139

35. Hartmann NB, von der Kammer F, Hofmann T, Baalousha M, Ottofuelling S, Baun A (2010) Algal testing of titanium dioxide nanoparticles - testing considerations, inhibitory effects and modification of cadmium bioavailability. Toxicology 269:190-197

36. Hebbalalu D, Lalley J, Nadagouda MN, Varma RS (2013) Greener techniques for the synthesis of silver nanoparticles using plant extracts, enzymes, bacteria, biodegradable polymers, and microwaves. ACS Sustain Chem Eng 1:703-712

37. Hu J, Wang J, Liu S, Zhang Z, Zhang H, Cai X, Pan J, Liu J (2018) Effect of $\mathrm{TiO}_{2}$ nanoparticle aggregation on marine microalgae Isochrysis galbana. J Environ Sci 66:208-215

38. Ighodaro O, Akinloye $O$ (2018) First line defence antioxidantssuperoxide dismutase (SOD), catalase (CAT) and glutathione peroxidase (GPX): their fundamental role in the entire antioxidant defence grid. Alex J Med 54:287-293

39. Ivask A, Juganson K, Bondarenko O, Mortimer M, Aruoja V, Kasemets K, Blinova I, Heinlaan M, Slaveykova V, Kahru A (2014) Mechanisms of toxic action of $\mathrm{Ag}, \mathrm{ZnO}$ and $\mathrm{CuO}$ nanoparticles to selected ecotoxicological test organisms and mammalian cells in vitro: a comparative review. Nanotoxicology 8:57-71

40. Janssen CR, Heijerick DG (2003) Algal toxicity tests for environmental risk assessments of metals. Reviews of environmental contamination and toxicology. Springer, Berlin

41. Kalman J, Paul KB, Khan FR, Stone V, Fernandes TF (2015) Characterisation of bioaccumulation dynamics of three differently coated silver nanoparticles and aqueous silver in a simple freshwater food chain. Environ Chem 12:662-672

42. Khaskel A, Barman P, Jana U (2015) L-tyrosine loaded nanoparticles: an efficient catalyst for the synthesis of dicoumarols and Hantzsch 1, 4-dihydropyridines. RSC Adv 5:13366-13373

43. Kierdaszuk B, Gryczynski I, Modrakz-Wojcik A, Bzowska A, Shugar D, Lakowicz JR (1995) Fluorescence of tyrosine and tryptophan in proteins using one-and two-photon excitation. Photochem Photobiol 61:319-324

44. Kleiven M, Macken A, Oughton DH (2019) Growth inhibition in Raphidocelis subcapita-evidence of nanospecific toxicity of silver nanoparticles. Chemosphere 221:785-792

45. Köser J, Engelke M, Hoppe M, Nogowski A, Filser J, Thöming J (2017) Predictability of silver nanoparticle speciation and toxicity in ecotoxicological media. Environ Sci Nano 4:1470-1483
46. Kusk KO, Christensen AM, Nyholm N (2018) Algal growth inhibition test results of 425 organic chemical substances. Chemosphere 204:405-412

47. Lazareva A, Keller AA (2014) Estimating potential life cycle releases of engineered nanomaterials from wastewater treatment plants. ACS Sustain Chem Eng 2:1656-1665

48. Lekamge S, Ball AS, Shukla R, Nugegoda D (2018) The toxicity of nanoparticles to organisms in freshwater. In: Voogt PD (ed) Reviews of environmental contamination and toxicology. Springer, New York

49. Lekamge S, Miranda AF, Ball AS, Shukla R, Nugegoda D (2019) The toxicity of coated silver nanoparticles to Daphnia carinata and trophic transfer from alga Raphidocelis subcapitata. PLoS ONE 14:e0214398

50. Li X, Schirmer K, Bernard L, Sigg L, Pillai S, Behra R (2015) Silver nanoparticle toxicity and association with the alga Euglena gracilis. Environ Sci Nano 2:594-602

51. Li Y, Zhang W, Niu J, Chen Y (2013) Surface-coating-dependent dissolution, aggregation, and reactive oxygen species (ROS) generation of silver nanoparticles under different irradiation conditions. Environ Sci Technol 47:10293-10301

52. Lu G, Yang H, Xia J, Zong Y, Liu J (2016) Toxicity of Cu and Cr Nanoparticles to Daphnia magna. Water Air Soil Pollut 228:18

53. Mcgillicuddy E, Murray I, Kavanagh S, Morrison L, Fogarty A, Cormican M, Dockery P, Prendergast M, Rowan N, Morris D (2017) Silver nanoparticles in the environment: sources, detection and ecotoxicology. Sci Total Environ 575:231-246

54. Melegari SP, Perreault F, Costa RHR, Popovic R, Matias WG (2013) Evaluation of toxicity and oxidative stress induced by copper oxide nanoparticles in the green alga Chlamydomonas reinhardtii. Aquat Toxicol 142:431-440

55. Merdzan V, Domingos RF, Monteiro CE, Hadioui M, Wilkinson KJ (2014) The effects of different coatings on zinc oxide nanoparticles and their influence on dissolution and bioaccumulation by the green alga, C. reinhardtii. Sci Total Environ 488:316-324

56. Miao A-J, Luo Z, Chen C-S, Chin W-C, Santschi PH, Quigg A (2010) Intracellular uptake: a possible mechanism for silver engineered nanoparticle toxicity to a freshwater alga Ochromonas danica. PLoS ONE 5:e15196

57. Miller RJ, Muller EB, Cole B, Martin T, Nisbet R, Bielmyer-Fraser GK, Jarvis TA, Keller AA, Cherr G, Lenihan HS (2017) Photosynthetic efficiency predicts toxic effects of metal nanomaterials in phytoplankton. Aquat Toxicol 183:85-93

58. Mittler R (2002) Oxidative stress, antioxidants and stress tolerance. Trends Plant Sci 7:405-410

59. Nanodatabase T (2019) Denmark: DTU environment, the Danish Ecological Council and Danish Consumer Council. http://nanod b.dk/. Accessed 23 Aug 2019

60. Navarro E, Baun A, Behra R, Hartmann NB, Filser J, Miao A-J, Quigg A, Santschi PH, Sigg L (2008) Environmental behavior and ecotoxicity of engineered nanoparticles to algae, plants, and fungi. Ecotoxicology 17:372-386

61. Navarro E, Piccapietra F, Wagner B, Marconi F, Kaegi R, Odzak N, Sigg L, Behra R (2008) Toxicity of silver nanoparticles to Chlamydomonas reinhardtii. Environ Sci Technol 42:8959-8964

62. Notter DA, Mitrano DM, Nowack B (2014) Are nanosized or dissolved metals more toxic in the environment? A meta-analysis. Environ Toxicol Chem 33:2733-2739

63. OECD (2011) Test no. 201: freshwater alga and cyanobacteria, growth inhibition test, growth inhibition test. OECD Publishing, Paris

64. OECD (2011) Test no. 201: freshwater alga and cyanobacteria, growth inhibition test. http://dx.doi.org/10.1787/9789264069 923-en. Accessed 13 Mar 2018

65. Oukarroum A, Bras S, Perreault F, Popovic R (2012) Inhibitory effects of silver nanoparticles in two green algae, Chlorella 
vulgaris and Dunaliella tertiolecta. Ecotoxicol Environ Saf 78:80-85

66. Petersen EJ, Diamond SA, Kennedy AJ, Goss GG, Ho K, Lead J, Hanna SK, Hartmann NB, Hund-Rinke K, Mader B (2015) Adapting OECD aquatic toxicity tests for use with manufactured nanomaterials: key issues and consensus recommendations. Environ Sci Technol 49:9532-9547

67. Piccapietra F, Allue CG, Sigg L, Behra R (2012) Intracellular silver accumulation in Chlamydomonas reinhardtii upon exposure to carbonate coated silver nanoparticles and silver nitrate. Environ Sci Technol 46:7390-7397

68. Pinzaru I, Coricovac D, Dehelean C, Moacă E-A, Mioc M, Baderca F, Sizemore I, Brittle S, Marti D, Calina CD (2018) Stable PEGcoated silver nanoparticles-a comprehensive toxicological profile. Food Chem Toxicol 111:546-556

69. Ponton DE, Croteau M-N, Luoma SN, Pourhoseini S, Merrifield RC, Lead JR (2019) Three-layered silver nanoparticles to trace dissolution and association to a green alga. Nanotoxicology 13:1-38

70. Potera C (2012) Understanding the germicidal effects of silver nanoparticles. Environ Health Perspect 120:a386

71. Qian H, Zhu K, Lu H, Lavoie M, Chen S, Zhou Z, Deng Z, Chen J, Fu Z (2016) Contrasting silver nanoparticle toxicity and detoxification strategies in Microcystis aeruginosa and Chlorella vulgaris: new insights from proteomic and physiological analyses. Sci Total Environ 572:1213-1221

72. Qu H, Linder SW, Mudalige TK (2017) Surface coating and matrix effect on the electrophoretic mobility of gold nanoparticles: a capillary electrophoresis-inductively coupled plasma mass spectrometry study. Anal Bioanal Chem 409:979-988

73. Ratirotjanakul W, Sioloetwong T, Suteewong T, Tangboriboonrat $\mathrm{P}$ (2018) Green synthesis of AgNPs coated mesoporous silica nanoparticles using tyrosine as reducing/stabilising agent. Mater Sci Forum 928:89-93

74. Ribeiro F, Gallego-Urrea JA, Jurkschat K, Crossley A, Hassellöv M, Taylor C, Soares AM, Loureiro S (2014) Silver nanoparticles and silver nitrate induce high toxicity to Pseudokirchneriella subcapitata, Daphnia magna and Danio rerio. Sci Total Environ 466:232-241

75. Rodrigues MA, Fernandes JN, Ruggiero R, Guerra W (2012) Palladium complex containing curcumin as ligand: thermal and spectral characterization. Am J Chem 2:157-159

76. Rodríguez-León $E$, Iñiguez-Palomares $R$, Navarro RE, HerreraUrbina R, Tánori J, Iñiguez-Palomares C, Maldonado A (2013) Synthesis of silver nanoparticles using reducing agents obtained from natural sources (Rumex hymenosepalus extracts). Nanoscale Res Lett 8:318

77. Römer I, White TA, Baalousha M, Chipman K, Viant MR, Lead JR (2011) Aggregation and dispersion of silver nanoparticles in exposure media for aquatic toxicity tests. J Chromatogr A 1218:4226-4233

78. Saei AA, Yazdani M, Lohse SE, Bakhtiary Z, Serpooshan V, Ghavami M, Asadian M, Mashaghi S, Dreaden EC, Mashaghi A, Mahmoudi M (2017) Nanoparticle surface functionality dictates cellular and systemic toxicity. Chem Mater 29:6578-6595

79. Salas P, Odzak N, Echegoyen Y, Kägi R, Sancho MC, Navarro E (2019) The role of size and protein shells in the toxicity to algal photosynthesis induced by ionic silver delivered from silver nanoparticles. Sci Total Environ 692:233-239

80. Schade S, Butler E, Gutsell S, Hodges G, Colbourne JK, Viant MR (2019) Improved algal toxicity test system for robust omicsdriven mode-of-action discovery in Chlamydomonas reinhardtii. Metabolites 9:94

81. Schultz AG, Boyle D, Chamot D, Ong KJ, Wilkinson KJ, Mcgeer JC, Sunahara G, Goss GG (2014) Aquatic toxicity of manufactured nanomaterials: challenges and recommendations for future toxicity testing. Environ Chem 11:207-226

82. Selvakannan P, Swami A, Srisathiyanarayanan D, Shirude PS, Pasricha R, Mandale AB, Sastry M (2004) Synthesis of aqueous $\mathrm{Au}$ core-Ag shell nanoparticles using tyrosine as a $\mathrm{pH}$ dependent reducing agent and assembling phase-transferred silver nanoparticles at the air-water interface. Langmuir 20:7825-7836

83. Shang L, Nienhaus K, Nienhaus GU (2014) Engineered nanoparticles interacting with cells: size matters. J Nanobiotechnol 12:1-11

84. Sharma VK, Siskova KM, Zboril R, Gardea-Torresdey JL (2014) Organic-coated silver nanoparticles in biological and environmental conditions: fate, stability and toxicity. Adv Coll Interface Sci 204:15-34

85. Slaveykova VI, Wilkinson KJ (2005) Predicting the bioavailability of metals and metal complexes: critical review of the biotic ligand model. Environ Chem 2:9-24

86. Smékalová $M$, Panáček $A$, Jančula $D$, Maršálek $B$, Kolařík J, Prucek R, Kvítek L, Zbořil R (2018) Culture medium mediated aggregation and re-crystallization of silver nanoparticles reduce their toxicity. Appl Mater Today 12:198-206

87. Snitsarev V, Young MN, Miller RM, Rotella DP (2013) The spectral properties of (-)-epigallocatechin 3-O-gallate (EGCG) fluorescence in different solvents: dependence on solvent polarity. PLoS ONE 8:e79834

88. Sørensen SN, Baun A (2015) Controlling silver nanoparticle exposure in algal toxicity testing: a matter of timing. Nanotoxicology 9:201-209

89. Souza TG, Ciminelli VS, Mohallem NDS (2016) A comparison of TEM and DLS methods to characterize size distribution of ceramic nanoparticles. In: Journal of physics: conference series, 2016. IOP Publishing, p 012039

90. Stebounova LV, Guio E, Grassian VH (2011) Silver nanoparticles in simulated biological media: a study of aggregation, sedimentation, and dissolution. J Nanopart Res 13:233-244

91. Sukhanova A, Bozrova S, Sokolov P, Berestovoy M, Karaulov A, Nabiev I (2018) Dependence of nanoparticle toxicity on their physical and chemical properties. Nanoscale Res Lett 13:44

92. Syafiuddin A, Salmiati S, Hadibarata T, Kueh ABH, Salim MR, Zaini MAA (2018) Silver nanoparticles in the water environment in Malaysia: inspection, characterization, removal, modeling, and future perspective. Sci Rep 8:986

93. Taylor C, Matzke M, Kroll A, Read DS, Svendsen C, Crossley A (2016) Toxic interactions of different silver forms with freshwater green algae and cyanobacteria and their effects on mechanistic endpoints and the production of extracellular polymeric substances. Environ Sci Nano 3:396-408

94. Tejamaya M, Romer I, Merrifield RC, Lead JR (2012) Stability of citrate, PVP, and PEG coated silver nanoparticles in ecotoxicology media. Environ Sci Technol 46:7011-7017

95. Tomaszewska E, Soliwoda K, Kadziola K, Tkacz-Szczesna B, Celichowski G, Cichomski M, Szmaja W, Grobelny J (2013) Detection limits of DLS and UV-vis spectroscopy in characterization of polydisperse nanoparticles colloids. J Nanomater 2013:1-10

96. Vale G, Mehennaoui K, Cambier S, Libralato G, Jomini S, Domingos RF (2016) Manufactured nanoparticles in the aquatic environment-biochemical responses on freshwater organisms: a critical overview. Aquat Toxicol 170:162-174

97. Varaprasad K, Mohan YM, Vimala K, Mohana Raju K (2011) Synthesis and characterization of hydrogel-silver nanoparticlecurcumin composites for wound dressing and antibacterial application. J Appl Polym Sci 121:784-796

98. von Moos N, Slaveykova VI (2014) Oxidative stress induced by inorganic nanoparticles in bacteria and aquatic 
microalgae-state of the art and knowledge gaps. Nanotoxicology 8:605-630

99. Wahid MH, Eroglu E, Chen X, Smith SM, Raston CL (2013) Entrapment of Chlorella vulgaris cells within graphene oxide layers. RSC Adv 3:8180-8183

100. Xia B, Chen B, Sun X, Qu K, Ma F, Du M (2015) Interaction of $\mathrm{TiO}_{2}$ nanoparticles with the marine microalga Nitzschia closterium: growth inhibition, oxidative stress and internalization. Sci Total Environ 508:525-533

101. Xia T, Kovochich M, Liong M, Mädler L, Gilbert B, Shi H, Yeh Jl, Zink Jl, Nel AE (2008) Comparison of the mechanism of toxicity of zinc oxide and cerium oxide nanoparticles based on dissolution and oxidative stress properties. ACS Nano 2:2121

102. Xiu Z-M, Zhang Q-B, Puppala HL, Colvin VL, Alvarez PJJ (2012) Negligible particle-specific antibacterial activity of silver nanoparticles. Nano Lett 12:4271-4275

103. Yin L, Cheng Y, Espinasse B, Colman BP, Auffan M, Wiesner M, Rose J, Liu J, Bernhardt ES (2011) More than the ions: the effects of silver nanoparticles on Lolium multiflorum. Environ Sci Technol 45:2360-2367
104. Zhang C, Hu Z, Deng B (2016) Silver nanoparticles in aquatic environments: physiochemical behavior and antimicrobial mechanisms. Water Res 88:403-427

105. Zhang L, Lei C, Chen J, Yang K, Zhu L, Lin D (2015) Effect of natural and synthetic surface coatings on the toxicity of multiwalled carbon nanotubes toward green algae. Carbon 83:198-207

106. Zhang W, Xiao B, Fang T (2018) Chemical transformation of silver nanoparticles in aquatic environments: mechanism, morphology and toxicity. Chemosphere 191:324-334

107. Zhao C-M, Wang W-X (2012) Importance of surface coatings and soluble silver in silver nanoparticles toxicity to Daphnia magna. Nanotoxicology 6:361-370

Publisher's Note Springer Nature remains neutral with regard to jurisdictional claims in published maps and institutional affiliations. 